\title{
Risk-Taking in Cooperative Banks: Do Board Characteristics Matter?
}

\author{
Antonio D'Amato \\ Assistant Professor of Corporate Finance \\ Department of Economics \& Statistics \\ University of Salerno \\ Fisciano (SA), Italy
}

\begin{abstract}
Based on a comprehensive dataset of Italian banks operating during the period 2006-2012 we examine whether board characteristics, specifically board turnover and education, affect the risk propensity of cooperative compared to joint-stock banks. Bank risk is measured by Z-index and profit volatility. Our findings show that cooperatives are less risk taker that joint stock banks, as predicted by both the theoretical and empirical literature, and have lower board turnover and education. Furthermore, we find that while board turnover does not mediate the relationship between the cooperative model and bank risk taking, we do find evidence for board education. The study reveals how low board education in cooperative banks, which is considered as weakness in current standards in corporate governance codes, acted as a (involuntary) "protection" for cooperative banks that prevent them from engaging in risky and more sophisticated projects whose risks cannot be understood by the management.
\end{abstract}

Keywords: Cooperative Banks, Board Turnover, Board Education, Bank Risk.

\section{Introduction}

In recent years, bank risk-taking has come under greater scrutiny by policy-makers reinforcing the on-going debate on the best practices in risk management and corporate governance among academics. However, in the literature there has been less emphasis so far on the understanding of the interplay between corporate governance, in particular the characteristics of the board of directors, and banks' risk-taking (Berger, Kick, \& Schaeck, 2014). This is surprising given that the board of directors is one of the key factors behind bank dynamics and its impact on bank risk and performance is widely recognized (Andres \& Vallelado, 2008; Pathan, 2009). However, the recent global financial crisis has resulted in a renovated debate over the importance of bank governance and banking authorities around the world have explicitly assigned a central role to the board of directors for a sound and prudent management of credit institutions.

In order to contribute to fill this gap in the literature, our work aims to analyse how and to what extent board of directors' characteristics impact on bank risk taking, focusing on the difference between cooperative and joint stock banks. The importance of this distinction is confirmed by the theoretical and empirical studies that has provided arguments and evidence on the different risk propensity between the two types of ownership model (Chaddad \& Cook, 2004; Fonteyne, 2007; Groeneveld \& de Vries, 2009; Hansmann, 2000). Hansmann (2000) highlights that during the US saving and loans crisis, investor-owned banks took on more speculative investment than mutual savings and loan association. Hesse \& Čihák (2007), based on a sample of 16577 banks from 29 OECD countries over the period 1994-2004, find that cooperative banks are more stable given that they have higher Z-index than commercial banks and a much lower volatility of their returns. The same results are found for EU countries by García-Marco \& Robles-Fernández (2008).

Although various studies have highlighted the difference in risk-taking between cooperative and joint stock banks, to the best of our knowledge no studies have directly related this difference to bank governance and specifically to board characteristics. The investigation of this topic has the potential to add new evidence on the on-going debate, very active in Europe, on how these differences in terms of business concepts and company models should be reflected in both banking regulation and corporate governance standards (see EACB, European Association of Co-operative Banks, 2015). This debate started soon after the crisis when cooperative banks stressed their superior ability to master the crisis much better than other banking groups. 
For instance, in Europe, where they represent $20 \%$ of the financial services market, write-offs by cooperative banks after the outbreak of the financial crisis was only $7 \%$. Based on previous theoretical and empirical work, we expect cooperative banks to be more risk-avoidant than joint stock banks and explore whether and to what extent board characteristics have a role on this relationship. In particular, among different board characteristics, we explore the role of board turnover and education. Corporate governance standards stress the importance of hiring directors with strong competences, as well as the risks associated with directors' entrenchment (low turnover). These two board characteristics seem to be problematic in cooperative organizations. As regards board education, empirical literature highlights that compared to directors of joint stock banks, cooperative directors do not always have high educational qualifications or professional experience in the field (Cornforth, 2004; Hardesty, 2005; Keeling, 2004; Shaw, 2006; Vitaliano, 1983). Schwizer and Stefanelli (2011), by analysing a sample of Italian BCCs showed that on average, $18 \%$ of the directors possess a Leaving Certificate from Middle School, $52 \%$ from High School and only 30\% have a university degree. Alexopoulos, Catturani, \& Goglio (2013) in their survey obtained similar results. With reference to board turnover, literature highlights that co-operative model characteristics increase the risk that board members become powerful and entrenched as they are insulated and protected from any kind of pressures both internal and external (Spear, 2004). In this respect, compared to joint stock, in cooperative bank there is a lowest level of board turnover (Battistin, Graziano, \& Parigi, 2012; Stefancic, 2014) and the board members are a 'self-perpetuating autocracy' (Nicols, 1967). The result is that cooperative directors remain in their charge for a long time.

Consequently, the question to answer is whether low board education and low board turnover can help justify the risk-aversion of cooperatives compared to joint stock banks. As regards the relationship between board turnover and risk taking, the literature suggests that directors who stay too long on corporate board have incentives to prefer a "quite life" and avoid risky projects which may affect their current positions and future benefits (Bertrand \& Mullainathan, 2003). As to the relationship between education and risk-taking, the empirical literature has found controversial evidence (Berger et al., 2014) but is in favour of the view that higher education is associated with higher risk-taking (Carducci \& Wong, 1998; Grable, 2000; Minton, Taillard, \& Williamson, 2014). Among others, Bertrand \& Schoar (2003) show that firms whose managers have an MBA seem to follow more aggressive strategies and run more levered company. Given these consideration, in this study we aim to answer the following research question:

RQ: Do board education and turnover mediate the relationship between bank institutional setting and risk taking?

Based on a comprehensive sample of Italian banks, we find that cooperatives are, as expected, more risk avoidant than joint stock banks, although they have a low level of board turnover and board education. Our estimations do not support the hypothesis on the mediation role of board turnover on the relationship between cooperative status and bank risk, but we find that board education mediates the relationship between the cooperative status and bank risk. This suggests that the low level of board education contributes to explain the low risk propensity of cooperative compared to joint stock banks. The rest of the work is organized as follows. In the next section we specify our empirical design and related methodological issues. The results are then presented and discussed. The last section concludes with the implications of our results and directions for future works.

\section{Research design: sample, variable and methodology}

To answer our research question, we refer to the Italian banking industry. We consider Italy an interesting case as this country has a large and well-developed system of cooperative banks (Becchetti, Garcia, \& Trovato, 2011; Bofondi \& Gobbi, 2006; Fiordelisi \& Mare, 2013; Giagnocavo, Gerez, \& Sforzi, 2012). Specifically, more than $70 \%$ of Italian banks is established as co-operative, while joint stock banks are the remaining (Statistical Database of the Bank of Italy, 2018). In terms of the generalization of our analysis to other context, it is worth noting that the Italian cooperative banks are similar in their objectives and main features to most of the cooperative banks in Europe as they are also part of the European Association of Co-operative Banks.

\subsection{Sample and data collection}

We test our research question on the population of Italian banks in the time-span 2006-2012. Based on the statistical information system of the Bank of Italy, we identify 727 cross-section units operative over the period 2006-2012. 
We also included banks that have started their business after 2006 as well as banks that closed down before 2012, but imposing as a constraint the availability of information for at least two consecutive years (Pathan, 2009). From this group we eliminated 89 banks due to the lack of data or missing information. Therefore, the final sample is composed of 638 banks of which 198 joint stock banks and 440 cooperative banks. We collected all the demographic information (bank name, location, age, etc.) related to the sampled Italian banks from the statistical information system of the Bank of Italy. As regards board characteristics, we collected this data through the consultation of governance reports available on banks website. We supplemented, when missing, this information through the consultation of ABI (Associazione Bancaria Italiana) Yearbooks. The Yearbook is yearly published by the Italian Banking Association and reports the composition of the governing bodies for each bank operating in Italy. From the database Bank Scope we collected the balance sheet data of each bank in our sample.

\subsection{The dependent variable-Bank risk}

Given our aim to study the relationship between institutional setting and bank risk taking, we proxy bank risk with the Z-index (De Nicoló, Jalal, \& Boyd, 2006; Laeven \& Levine, 2009; Pathan, 2009). This measure is calculated as the sum of the equity-asset ratio (or capital-asset ratio-CAR-) and the return on assets (ROA) divided by an estimation of the ROA's standard deviation. A higher Z-index highlights that a bank is less risky and thus more stable. Following the approach used by Delis \& Staikouras (2011) we compute the Z-index as:

$$
Z_{i, t}=\frac{R O A_{i, t}+C A R_{i, t}}{\sigma(R O A)_{i, t}}
$$

Where $R O A_{i, t}$ and $C A R_{i, t}$ are respectively the return on asset and the equity-asset ratio of bank $i$ in the period $t$ calculated at the end of the fiscal year. The ROA is calculated as the ratio between the profit before tax on total assets. To compute $\sigma(\mathrm{ROA})_{\mathrm{i}, \mathrm{t}}$ of bank $i$ in the period $t$ we used data from two period $(t, t-1)$ in order to capture the short-term fluctuations of bank risk (Delis, Hasan, \& Tsionas, 2014). Furthermore, in line with recent empirical studies, we also used the standard deviation of profit as dependent variable $-\sigma(\mathrm{ROA})_{i, t},($ Delis \& Staikouras, 2009; Schaeck \& Cihák, 2014).

\subsection{Key independent and control variables}

To investigate our research question that relate to the relationship between risk taking and bank institutional setting, the key independent variable is a dummy variable equal to 1 for cooperative banks. Joint stock banks is the baseline category. In order to control the factors that could affect the bank risk taking, we also consider a set of control variables at bank and board levels. At bank level we control for bank size, bank age and the ratio between loans and total assets as a proxy of bank business model (Andres \& Vallelado, 2008). We measure bank size as the natural log of total assets at the end of the fiscal year. Bank age is the natural log of the age of a bank. Furthermore, we consider a dummy variable for listed banks that equal 1 if the bank $i$ in the period $t$ is listed in a stock market, 0 otherwise. In general, listed companies are more scrutinized by investors, authorities, stock market, etc. (Dyck, Morse, \& Zingales, 2010) and thus, are expected to manage their risks more closely. Moreover, we include i) a variable to control for the abnormal level of NPL, measured as a dummy variable equal to 1 if the NPL score of the bank $i$ in the year $t$ is higher to the 90th percentile, 0 otherwise, ii) a variable to control for bank growth measured as the growth rate of bank assets and iii) a dummy variable equal to 1 if the bank $i$ in time $t$ fulfilled an acquisition, 0 otherwise. On a board level we consider the board size expressed by its natural $\log$ (Chaganti, Mahajan, \& Sharma, 1985; Nakano \& Nguyen, 2012; Pathan, 2009) and the gender diversity expressed by the proportion of female directors on board (Beck, Behr, \& Guettler, 2013; Bellucci, Borisov, \& Zazzaro, 2010; Berger et al., 2014; Palvia, Vähämaa, \& Vähämaa, 2014). Furthermore, we consider the board turnover and education. Following Eldenburg, Hermalin, Weisbach, \& Wosinska (2004) our proxy for board turnover is

$$
\frac{(\text { N.of new directorsat } t)+(\text { N.of directorsthat left the board between } t \text { and } t-1)}{2 \times(\text { Boardsize at } t-1)}
$$

As concerns the board education, ideally, proxy for board education would include detailed information about the degree level, the main subject studies and the academic institutions that awarded the degree for each director. Unfortunately, not all this information is always available, especially for cooperative banks. But we were able to have information about the directors with at least a university degree at the moment of their appointment. Therefore, we proxy board education of bank $i$ in period $t$ as the proportion of director who hold a university degree. 
Finally, we also considered the CEO duality and the proportion of independent directors as control variables. Although the literature shows that CEO duality and the proportion of independent directors are two important corporate governance variables we did not control for these because in Italian cooperative banks the role of the CEO is taken by the board as a whole prevailingly. As concerns the independent directors, they are not easily identifiable in cooperative banks. In cooperative banks, directors are elected among the owners, who are also customers of the bank, both as depositors or debtors. Therefore, it is doubtful whether the directors are independent (Basel Committee on Banking Supervision, 2015; European Association of Co-operative Banks, 2015). For this reason, we considered not appropriate to control for this variable which would create multi collinearity problems with the dummy for cooperatives. To limit spurious relationships related to differences in the economic, social and cultural conditions of the various Italian geographical areas that could affect bank risk, we controlled for bank location and GDP (Beck, De Jonghe, \& Schepens, 2013; Boytsun, Deloof, \& Matthyssens, 2011; Guiso, Sapienza, \& Zingales, 2009). We created three dummy variables for Northwest Italy, the Central and South and Islands. The Northeast area is used as a baseline.

All models are estimated taking into account the time fixed effects to control changes in macroeconomic conditions or in supervisory approach.

\subsection{Summary statistics}

Table 1 presents the descriptive statistics for our main variables. Table 2 shows the mean comparison between Joint Stock and Cooperative banks. Finally, Table 3 presents the correlation matrix.

Table 1 - Summary statistics

\begin{tabular}{lrrrrr}
\hline Variable & Obs. & Mean & Std. Dev. & Min & \multicolumn{1}{c}{ Max } \\
\hline & & & & & \\
Z-index & 3489 & 284.4 & 1021.450 & 1 & 14378.830 \\
$\sigma($ ROA) & 3489 & 0.003 & 0.007 & 0 & 0.170 \\
Bank size (€/billion) & 4161 & 3,92 & 18,7 & 0.003214 & 431 \\
Bank age (year) & 4161 & 58.135 & 43.602 & 0.5 & 183 \\
Business model (Loans/TA) & 4161 & 0.659 & 0.184 & 0.006 & 0.990 \\
Growth rate & 3494 & 0.199 & 5.542 & -0.835 & 326.872 \\
Roe & 4160 & 0.048 & 0.093 & -0.741 & 0.912 \\
Board size & 4161 & 9.740 & 2.831 & 5 & 24 \\
Gender diversity & 4161 & 0.047 & 0.073 & 0 & 0.444 \\
Board turnover & 4157 & 0.125 & 0.198 & 0 & 1.417 \\
Board education & 4131 & 0.394 & 0.326 & 0 & 1 \\
& & & & &
\end{tabular}

As shown in Table 1 most of the Italian banks have a strong focus on traditional and core activities, as $66 \%$ of their assets is composed by customers' loans, their asset growth is about $20 \%$ with an average profitability of $4,8 \%$. The size of bank board is about 10 members, of which only $4.7 \%$ are female directors. As to our key variables, at the banking system level, the board turnover is $12.5 \%$ and board education is $39.4 \%$.

Table 2 - Univariate Tests of difference between joint-stock and cooperative banks

\begin{tabular}{|c|c|c|c|}
\hline Variable & Joint Stock Banks & Cooperative Banks & t-value \\
\hline Z-index $(\ln )$ & 4.042 & 4.539 & $-9.759 * * *$ \\
\hline$\sigma(\mathrm{ROA})(\ln )$ & -6.413 & -6.675 & $5.026 * * *$ \\
\hline Bank size $(\ln )$ & 21.458 & 19.324 & $48.754 * * *$ \\
\hline Bank age $(\ln )$ & 2.967 & 3.898 & $-27.176 * * *$ \\
\hline Business model (Loans/TA) & 0.640 & 0.668 & $-4.535 * * *$ \\
\hline Growth rate & 0.441 & 0.092 & $1.716^{*}$ \\
\hline Roe $(\ln )$ & 0.041 & 0.043 & -0.305 \\
\hline Board size $(\ln )$ & 2.333 & 2.192 & $14.932 * * *$ \\
\hline Gender diversity & 0.035 & 0.052 & $-6.854 * * *$ \\
\hline Board turnover $(\ln )$ & 0.152 & 0.085 & $12.950 * * *$ \\
\hline Board education & 0.766 & 0.228 & $75.717 * * *$ \\
\hline No of obs. & 1294 & 2867 & \\
\hline
\end{tabular}


As shown in Table 2 there are significant differences between joint stock and cooperative banks with reference to bank structure and board characteristics. In particular, compared to joint stock, cooperative banks are smaller in size $(\mathrm{t}=48.754, \mathrm{p}<0.1 \%)$ and are more aged $(\mathrm{t}=-27.176, \mathrm{p}<0.1 \%)$. Their business model is primarily based on loans activity $(\mathrm{t}=-4.535, \mathrm{p}<0.1 \%)$. Compared to the board of joint stock banks the board of directors in cooperative banks is smaller in size $(\mathrm{t}=14.932, \mathrm{p}<0.1 \%)$ with a higher proportion of female directors $(\mathrm{t}=-$ $6.854, \mathrm{p}<0.1 \%)$. In addition, in cooperative banks both board turnover $(\mathrm{t}=12.95, \mathrm{p}<0.1 \%)$ and board education $(\mathrm{t}=75.717, \mathrm{p}<0.1 \%)$ are significantly lower than in joint stock banks.

Finally, joint stock and cooperative banks differ significantly as regards their risk levels. Specifically, cooperative show higher Z-index $(\mathrm{t}=-9.759, \mathrm{p}<0.1 \%)$ and lower standard deviation of $\mathrm{ROA}(\mathrm{t}=5.026, \mathrm{p}<0.1 \%)$ than joint stock banks.

From Table 3 we can see that correlation coefficients between our main variables are quite low, thus we can retain that multicollinearity problems in our models are modest. In particular, we note that both board turnover and board education are significantly associated with bank risk level. The board turnover is negatively associated with bank risk, thus an increase in director turnover lead to low bank solidity $-Z$-index $-(\rho=-0.113, p<0.1 \%)$ and high profit volatility $-\sigma(\mathrm{ROA})-(\rho=0.135, \mathrm{p}<0.1 \%)$. At the same time the board education is negatively associated with bank risk measured as Z-index $(\rho=-0.216, p<0.1 \%)$ and profit volatility $(\rho=0.185, p<0.1 \%)$. Therefore, an increase in directors' education leads to low bank solidity and high profit volatility.

\subsection{Methodology}

In order to investigate the relationship between bank risk and bank institutional setting we estimate the following panel model:

$$
\text { Bank risk }_{i, t}=\beta_{0}+\beta_{1} \text { Cooperative }_{i, t}+\beta_{j} \text { Control variables }_{i, t}+\beta_{k} \text { Years }+\varepsilon
$$

Bank risk is Z-index and ROA's standard deviation, alternatively. We use a dynamic panel approach to estimate model [1], including a lagged dependent variable as regressor to take into account the dynamic nature of risk (Delis \& Kouretas, 2011; Köhler, 2014). In particular, we opt for a 2SLS-IV approach because of the endogeneity issue in our model due to i) the lagged dependent variable and ii) corporate governance variables (Board size, Female on Board, Board Turnover and Board Education). On the contrary, we treated our key independent variable, the proxy for the institutional setting, as exogenous (Gorton \& Schmid, 1999). To control for endogeneity, we instrument these variables with their own first and second lags.

To test the instruments validity, we use the Hansen $J$-statistic of over-identifying restrictions. In addition, we test the presence of first and second order serial correlation. The absence of second-order serial correlation denotes that the model is correctly specified and therefore there is no omitted variables bias.

To answer our research question on the existence of a mediation effect of board turnover and board education on the relationship between institutional setting and bank risk taking we follow the approach of Baron \& Kenny (1986) (Tab. 7). Therefore, as first step, we test the existence of a significant relationship between the independent variable and the mediators by estimating the following panel models:

$$
\begin{aligned}
& \text { Board turnover }_{i, t}=\beta_{0}+\beta_{1} \text { Cooperative }_{i, t}+\beta_{j} \text { Control variables }_{i, t}+\beta_{k} \text { Years }+\varepsilon \\
& \text { Board education }_{i, t}=\beta_{0}+\beta_{1} \text { Cooperative }_{i, t}+\beta_{j} \text { Control variables }_{i, t}+\beta_{k} \text { Years }+\varepsilon
\end{aligned}
$$


Table 3 - Correlation matrix - Pearson coefficients

\begin{tabular}{|c|c|c|c|c|c|c|c|c|c|c|c|}
\hline & 1 & 2 & 3 & 4 & 5 & 6 & 7 & 8 & 9 & 10 & 12 \\
\hline 1. Z-index $(\ln )$ & 1 & & & & & & & & & & \\
\hline 2. $\sigma(\mathrm{ROA})(\ln )$ & $-0.501 * * *$ & 1 & & & & & & & & & \\
\hline 3. Bank size $(\ln )$ & $-0.055^{* *}$ & $-0.053 * *$ & 1 & & & & & & & & \\
\hline 4. Bank age $(\ln )$ & $0.195 * * *$ & $-0.147 * * *$ & $-0.075^{* * *}$ & 1 & & & & & & & \\
\hline 5. Business model & $0.122 * * *$ & $-0.177 * * *$ & $0.149 * * *$ & $0.165^{* * *}$ & 1 & & & & & & \\
\hline 6. Growth rate & $-0.041 *$ & $0.058 * * *$ & 0.013 & $-0.057 * * *$ & 0.001 & 1 & & & & & \\
\hline 7. GDP & $0.166^{* * *}$ & $-0.047 * *$ & -0.014 & 0.013 & $0.056^{* *}$ & -0.018 & 1 & & & & \\
\hline 8. $\operatorname{ROE}(\ln )$ & $0.292 * * *$ & $-0.325^{* * *}$ & $0.106^{* * *}$ & $0.059 * * *$ & $-0.089 * * *$ & $-0.060 * *$ & $0.118^{* * *}$ & 1 & & & \\
\hline 9. Board size $(\ln )$ & $-0.028 \dagger$ & -0.027 & $0.489 * * *$ & $-0.157 * * *$ & $0.088^{* * *}$ & -0.018 & -0.019 & $0.038^{*}$ & 1 & & \\
\hline 10. Gender diversity & -0.003 & -0.022 & $-0.041 * *$ & $0.084 * * *$ & $0.036^{*}$ & -0.013 & $-0.058 * * *$ & $-0.045 * *$ & 0.013 & 1 & \\
\hline 11. Board turnover $(\ln )$ & $-0.113 * * *$ & $0.135^{* * *}$ & $0.103 * * *$ & $-0.175^{* * *}$ & $-0.063 * * *$ & $0.066^{* * *}$ & -0.018 & $-0.096 * * *$ & $0.070 * * *$ & $0.085^{* * *}$ & \\
\hline 12. Board education & $-0.216^{* * *}$ & $0.185^{* * *}$ & $0.499 * * *$ & $-0.379 * * *$ & $-0.197 * * *$ & $0.057 * * *$ & $-0.041 * *$ & -0.025 & $0.191^{* * *}$ & $-0.049 * * 0.205 * * *$ & 1 \\
\hline \multicolumn{12}{|c|}{$\begin{array}{l}\text { Z-index is the natural logarithm of Z-index. } \sigma(\mathrm{ROA}) \text { is the natural logarithm of ROA standard deviation. Bank size denotes the natural logarithm of tota } \\
\text { assets. Bank age denotes the natural logarithm of the age of a bank. Business model is the ratio of loans to total assets as a proxy for the bank busines } \\
\text { model. Growth rate is the growth rate of total assets. GDP is the Gross Domestic product. ROE is the natural logarithm of bank profitability. Board size is the } \\
\text { natural logarithm of the number of board members. Gender diversity denotes the proportion of female members on the board. Board turnover denotes the } \\
\text { natural logarithm of board member turnover. Board education is the proportion of director who hold a university degree. } \dagger, *, * *, * * * \text { denote significance a } \\
\text { the } 10 \%, 5 \%, 1 \% \text { and } 0.1 \% \text { levels respectively. }\end{array}$} \\
\hline
\end{tabular}

In the second step we estimate the relationship between the independent variable (cooperative bank dummy) and the bank risk. To this aim, we use the model [1] less board turnover and board education as control variables. In the third step we test the relationship between the mediators (board turnover and education) and the dependent variable (model [1] less the independent variable). Finally, in the last step we test the full model [1]. The existence of a mediation effect may not be rejected if the impact of the independent variable on the dependent is reduced or cancelled when mediators are added to the model. Therefore, the dummy for cooperative bank affects the dependent variable through board turnover and board education.

\section{Results}

In Table 4 we present the results of our analyses. All models are significant, the Hansen's $J$ test statistic of over identifying restrictions and the serial-correlation tests do not reject the null hypothesis of correct specification. Therefore, instruments are exogenous and no serial correlation problems exist in the models. Although the models indicate the presence of first-order autocorrelation $(\Pi 1)$, since $\Pi 1$ is statistically significant, our results are not inconsistent because second order autocorrelation (II2) is not significant (Blundell \& Bond, 1998). Finally, we note that in all the estimated models the control variables have the expected signs and the lagged dependent variables are also significant, thus bank risk is persistent. In particular, when lagged dependent coefficient is significant and between 0 and 1 this suggests that risk persist but will eventually return to its average level.

As regards the relationship between our key independent variable (cooperative dummy) and bank risk, coherent with the literature we find a significant association between Cooperative dummy and the bank risk. In particular, in column (3), we note a positive association between cooperative dummy and the Z-index $(\beta=0.257, \mathrm{p}<1 \%)$. In column (7), we note a negative association between cooperative dummy and the profit volatility $-\sigma(\mathrm{ROA})-(\beta=$ $-0.323, \mathrm{p}<0.1 \%)$. Therefore, we conclude that cooperative are more stable and their profitability is less volatile than joint stock banks.

Subsequently we test if board turnover and education could explain this result by investigating a mediation framework. To test the mediating effect of board turnover and education on the relationship between cooperative status and bank risk, we follow Baron and Kenny (1986) approach. Therefore, as stated previously we first estimate the models [2] and [3]. Accordingly, Table 4 presents the results of these two models in columns (1) and (2) respectively using robust standard errors. Our results indicate that the dummy for cooperative bank status has a highly significant and negative effect on board turnover $(\beta=-0.046, \mathrm{p}<0.1 \%)$ and on board education $(\beta=-$ $0.458, \mathrm{p}<0.1 \%$ ). Thus, we conclude that in cooperative banks board turnover and education are significantly lower than in joint stock banks. 
International Journal of Business and Social Science Vol. $9 \cdot$ No. $11 \cdot$ November 2018 doi:10.30845/ijbss.v9n11p10

Table 4 - Regression results of bank risk measured through the Z-index and $\sigma($ ROA) - 2SLS-IV approach

\begin{tabular}{|c|c|c|c|c|c|c|c|c|c|c|}
\hline Dependent & $\begin{array}{c}\text { Board } \\
\text { turnover }\end{array}$ & $\begin{array}{c}\text { Board } \\
\text { education }\end{array}$ & Z-index & Z-index & Z-index & Z-index & $\sigma(\mathrm{ROA})$ & $\sigma(\mathrm{ROA})$ & $\sigma(\mathrm{ROA})$ & $\sigma(\mathrm{ROA})$ \\
\hline & 1 & 2 & 3 & 4 & 5 & 6 & 7 & 8 & 9 & 10 \\
\hline Lagged dependent & & & $\begin{array}{c}0.520 * * * \\
(4.43)\end{array}$ & $\begin{array}{c}0.477 * * * \\
(3.94)\end{array}$ & $\begin{array}{c}0.554 * * * \\
(4.85)\end{array}$ & $\begin{array}{c}0.484 * * * \\
(3.97)\end{array}$ & $\begin{array}{c}0.522 * * * \\
(4.60)\end{array}$ & $\begin{array}{c}0.474 * * * \\
(3.91)\end{array}$ & $\begin{array}{c}0.546^{* * * *} \\
(4.85)\end{array}$ & $\begin{array}{c}0.478^{* * * *} \\
(3.95)\end{array}$ \\
\hline Bank size & $\begin{array}{c}0.0018 \\
(0.54)\end{array}$ & $\begin{array}{c}0.0221 * * \\
(3.16)\end{array}$ & $\begin{array}{c}0.0178 \\
(0.62)\end{array}$ & $\begin{array}{c}0.00867 \\
(0.28)\end{array}$ & $\begin{array}{c}0.00957 \\
(0.30)\end{array}$ & $\begin{array}{c}0.0266 \\
(0.84)\end{array}$ & $\begin{array}{c}-0.0836^{*} \\
(-2.54)\end{array}$ & $\begin{array}{c}-0.0723 \dagger \\
(-1.86)\end{array}$ & $\begin{array}{c}-0.0707 \dagger \\
(-1.92)\end{array}$ & $\begin{array}{c}-0.0977^{*} \\
(-2.57)\end{array}$ \\
\hline Bank age & $\begin{array}{l}-0.0013 \\
(-0.38)\end{array}$ & $\begin{array}{c}-0.0270 * * \\
(-3.12)\end{array}$ & $\begin{array}{c}0.115^{* *} \\
(3.01)\end{array}$ & $\begin{array}{c}0.148 * * * \\
(3.55)\end{array}$ & $\begin{array}{c}0.135 * * \\
(3.19)\end{array}$ & $\begin{array}{c}0.136^{* *} \\
(3.25)\end{array}$ & $\begin{array}{c}-0.0856^{*} \\
(-2.45)\end{array}$ & $\begin{array}{c}-0.118^{* *} \\
(-2.88)\end{array}$ & $\begin{array}{c}-0.106^{* *} \\
(-2.62)\end{array}$ & $\begin{array}{l}-0.100^{*} \\
(-2.53)\end{array}$ \\
\hline Business model & $\begin{array}{l}-0.044 \dagger \\
(-1.74)\end{array}$ & $\begin{array}{c}-0.000838 \\
(-0.03)\end{array}$ & $\begin{array}{l}-0.0473 \\
(-0.26)\end{array}$ & $\begin{array}{l}-0.176 \\
(-0.86)\end{array}$ & $\begin{array}{l}-0.131 \\
(-0.65)\end{array}$ & $\begin{array}{l}-0.161 \\
(-0.80)\end{array}$ & $\begin{array}{c}0.0603 \\
(0.32)\end{array}$ & $\begin{array}{l}0.177 \\
(0.82)\end{array}$ & $\begin{array}{l}0.130 \\
(0.62)\end{array}$ & $\begin{array}{l}0.149 \\
(0.71)\end{array}$ \\
\hline Growth rate & & & $\begin{array}{l}-0.0685 \\
(-0.40)\end{array}$ & $\begin{array}{c}0.0187 \\
(0.10)\end{array}$ & $\begin{array}{c}0.0224 \\
(0.12)\end{array}$ & $\begin{array}{c}0.0151 \\
(0.08)\end{array}$ & $\begin{array}{l}-0.275 \\
(-1.18)\end{array}$ & $\begin{array}{l}-0.341 \\
(-1.35)\end{array}$ & $\begin{array}{l}-0.367 \\
(-1.48)\end{array}$ & $\begin{array}{l}-0.332 \\
(-1.36)\end{array}$ \\
\hline Listed bank & $\begin{array}{l}-0.003 \\
(-0.16)\end{array}$ & $\begin{array}{c}0.0898 * \\
(2.50)\end{array}$ & $\begin{array}{c}-0.0512 \\
(-0.32)\end{array}$ & $\begin{array}{l}-0.124 \\
(-0.66)\end{array}$ & $\begin{array}{l}-0.137 \\
(-0.72)\end{array}$ & $\begin{array}{l}-0.109 \\
(-0.58)\end{array}$ & $\begin{array}{l}0.111 \\
(0.67)\end{array}$ & $\begin{array}{l}0.197 \\
(1.04)\end{array}$ & $\begin{array}{l}0.185 \\
(0.97)\end{array}$ & $\begin{array}{l}0.172 \\
(0.90)\end{array}$ \\
\hline M\&A & & & $\begin{array}{l}-0.226 \\
(-1.41)\end{array}$ & $\begin{array}{l}-0.363 \dagger \\
(-1.90)\end{array}$ & $\begin{array}{l}-0.370 \dagger \\
(-1.90)\end{array}$ & $\begin{array}{l}-0.375 \dagger \\
(-1.94)\end{array}$ & $\begin{array}{c}0.349^{*} \\
(2.11)\end{array}$ & $\begin{array}{c}0.467^{*} \\
(2.29)\end{array}$ & $\begin{array}{c}0.483^{*} \\
(2.34)\end{array}$ & $\begin{array}{l}0.476^{*} \\
(2.32)\end{array}$ \\
\hline Performance & $\begin{array}{c}-0.377 * * * \\
(-3.87)\end{array}$ & $\begin{array}{c}0.280 * * \\
(2.67)\end{array}$ & & & & & & & & \\
\hline Abnormal NPL & & & $\begin{array}{c}-0.585^{* * * *} \\
(-5.14)\end{array}$ & $\begin{array}{c}-0.674 * * * \\
(-5.36)\end{array}$ & $\begin{array}{c}-0.652 * * * \\
(-5.16)\end{array}$ & $\begin{array}{c}-0.672 * * * \\
(-5.31)\end{array}$ & $\begin{array}{c}0.515 * * * \\
(4.64)\end{array}$ & $\begin{array}{c}0.589 * * * \\
(4.66)\end{array}$ & $\begin{array}{c}0.584 * * * \\
(4.59)\end{array}$ & $\begin{array}{c}0.586 * * * \\
(4.63)\end{array}$ \\
\hline GDP & & & $\begin{array}{c}8.162 * * \\
(3.11)\end{array}$ & $\begin{array}{c}8.164 * * \\
(3.05)\end{array}$ & $\begin{array}{c}8.333 * * \\
(3.04)\end{array}$ & $\begin{array}{c}8.105^{* *} \\
(3.02)\end{array}$ & $\begin{array}{c}-6.719 * \\
(-2.49)\end{array}$ & $\begin{array}{l}-6.682 * \\
(-2.45)\end{array}$ & $\begin{array}{c}-7.021^{*} \\
(-2.52)\end{array}$ & $\begin{array}{l}-6.578^{*} \\
(-2.41)\end{array}$ \\
\hline Board size & $\begin{array}{l}0.004 \\
(0.30)\end{array}$ & $\begin{array}{c}-0.0763 * * * \\
(-4.08)\end{array}$ & $\begin{array}{c}0.0392 \\
(0.28)\end{array}$ & $\begin{array}{c}0.0890 \\
(0.49)\end{array}$ & $\begin{array}{l}0.170 \\
(0.93)\end{array}$ & $\begin{array}{c}0.0899 \\
(0.50)\end{array}$ & $\begin{array}{l}-0.0313 \\
(-0.22)\end{array}$ & $\begin{array}{c}-0.0746 \\
(-0.38)\end{array}$ & $\begin{array}{l}-0.163 \\
(-0.81)\end{array}$ & $\begin{array}{l}-0.0687 \\
(-0.35)\end{array}$ \\
\hline Female on board & $\begin{array}{l}-0.021 \\
(-0.47)\end{array}$ & $\begin{array}{c}0.0401 \\
(0.46)\end{array}$ & $\begin{array}{l}0.138 \\
(0.33)\end{array}$ & $\begin{array}{l}0.194 \\
(0.45)\end{array}$ & $\begin{array}{c}0.0230 \\
(0.05)\end{array}$ & $\begin{array}{l}0.125 \\
(0.28)\end{array}$ & $\begin{array}{l}-0.250 \\
(-0.59)\end{array}$ & $\begin{array}{l}-0.331 \\
(-0.74)\end{array}$ & $\begin{array}{l}-0.118 \\
(-0.26)\end{array}$ & $\begin{array}{l}-0.242 \\
(-0.53)\end{array}$ \\
\hline \multicolumn{11}{|l|}{ Independent } \\
\hline Cooperative & $\begin{array}{c}-0.046^{* * *} \\
(-3.85)\end{array}$ & $\begin{array}{c}-0.458 * * * \\
(-18.21)\end{array}$ & $\begin{array}{c}0.257 * * \\
(2.84)\end{array}$ & & $\begin{array}{c}0.367 * * \\
(3.10)\end{array}$ & $\begin{array}{l}0.191 \\
(1.46)\end{array}$ & $\begin{array}{c}-0.323 * * * \\
(-3.45)\end{array}$ & & $\begin{array}{c}-0.422 * * * \\
(-3.32)\end{array}$ & $\begin{array}{c}-0.264 * \\
(-1.98)\end{array}$ \\
\hline \multicolumn{11}{|l|}{ Mediator } \\
\hline Board turnover & & $\begin{array}{l}-0.0215 \\
(-0.80)\end{array}$ & & $\begin{array}{l}2.052 \\
(1.51)\end{array}$ & $\begin{array}{l}2.304 \\
(1.60)\end{array}$ & $\begin{array}{l}2.145 \\
(1.57)\end{array}$ & & $\begin{array}{l}-1.701 \\
(-1.01)\end{array}$ & $\begin{array}{l}-2.124 \\
(-1.20)\end{array}$ & $\begin{array}{l}-1.720 \\
(-1.02)\end{array}$ \\
\hline Board education & $\begin{array}{l}0.002 \\
(0.11)\end{array}$ & & & $\begin{array}{c}-0.536 * * * \\
(-3.31)\end{array}$ & & $\begin{array}{c}-0.397 * \\
(-2.17)\end{array}$ & & $\begin{array}{c}0.536^{* *} \\
(3.21)\end{array}$ & & $\begin{array}{c}0.343^{*} \\
(1.99)\end{array}$ \\
\hline Constant & $\begin{array}{l}0.096 \\
(1.58)\end{array}$ & $\begin{array}{c}0.418^{* *} \\
(2.97)\end{array}$ & $\begin{array}{l}1.471^{*} \\
(2.04)\end{array}$ & $\begin{array}{c}1.845^{* *} \\
(2.62)\end{array}$ & $\begin{array}{l}0.834 \\
(1.02)\end{array}$ & $\begin{array}{l}1.292 \\
(1.51)\end{array}$ & $\begin{array}{l}-0.860 \\
(-1.23)\end{array}$ & $\begin{array}{c}-1.531^{*} \\
(-2.22)\end{array}$ & $\begin{array}{l}-0.418 \\
(-0.53)\end{array}$ & $\begin{array}{l}-0.799 \\
(-0.96)\end{array}$ \\
\hline Year dummies & yes & yes & yes & yes & yes & yes & yes & yes & yes & yes \\
\hline Location dummies & yes & yes & yes & yes & yes & yes & yes & yes & yes & yes \\
\hline $\mathrm{N}$ & 2453 & 2450 & 2096 & 2091 & 2095 & 2091 & 2096 & 2091 & 2095 & 2091 \\
\hline $\mathrm{F}$ & $144.48 * * *$ & $1116.1 * * *$ & $23.52 * * *$ & $20.41 * * *$ & $20.21 * * *$ & $19.61 * * *$ & $22.11 * * *$ & $19.14 * * *$ & $19.61 * * *$ & $18.90 * * *$ \\
\hline Hansen $J$ & 3.293 & 2.298 & 1.803 & 4.477 & 0.246 & 4.016 & 1.218 & 6.123 & 0.676 & 5.517 \\
\hline$\Pi 1$ & & & $-2.62 * *$ & $-2.22^{*}$ & $-2.78 * *$ & $-2.24^{*}$ & $-2.72 * *$ & $-2.24^{*}$ & $-2.82 * *$ & $-2.27^{*}$ \\
\hline$\Pi 2$ & & & -0.82 & -1.09 & -1.33 & -1.14 & -0.66 & -0.89 & -1.14 & -0.92 \\
\hline $\begin{array}{l}\text { This table reports th } \\
\text { risk taking. Bank siz } \\
\text { assets as a proxy for } \\
\text { market. M\&A is a d } \\
\text { dummy variable equ } \\
\text { Board size is the nat } \\
\text { to } 1 \text { if a bank is a co } \\
\text { hold a university de } \\
\text { heteroskedasticity an }\end{array}$ & $\begin{array}{l}\text { sion (2SLS-I } \\
\text { es the natural } \\
\mathrm{k} \text { business } \mathrm{m} \\
\text { variable equa } \\
\text { if the NPL/G } \\
\text { arithm of the } \\
\text { ve and } 0 \text { othe } \\
\text { ear and loca } \\
\text { orrelation. } \dagger \text {, }\end{array}$ & $\begin{array}{l}\text { results of the } \\
\text { garithm of to } \\
\text { del. Growth ro } \\
\text { to } 1 \text { if a bank } \\
\text { ss Loans ratic } \\
\text { imber of boar } \\
\text { ise. Board tur } \\
\text { on dummies } \\
* *, * * * \text { deno }\end{array}$ & $\begin{array}{l}\text { assets. Ban } \\
\text { is the grov } \\
\text { cquires ano } \\
\text { f a bank is } \\
\text { nembers. G } \\
\text { over denotes } \\
\text { ntrol for ye } \\
\text { significance }\end{array}$ & $\begin{array}{l}\text { age denotes } \\
\text { rate of bank in a } \\
\text { gher or lowe } \\
\text { der diversity } \\
\text { he natural lo } \\
\text { and locatio } \\
\text { t the } 10 \%, 5 \%\end{array}$ & $\begin{array}{l}\text { natural log } \\
\text { Listed ban } \\
\text { ven year. } \\
\text { han the } 90 \mathrm{t} \\
\text { enotes the pr } \\
\text { rithm of boa } \\
\text { fixed effects } \\
1 \% \text { and } 0.10\end{array}$ & $\begin{array}{l}\text { thm of the } \\
\text { s a dummy } \\
\text { ormance is } \\
\text { or } 10 \text { th perc } \\
\text { ortion of fe } \\
\text { member tu } \\
\mathrm{Z} \text { values ar } \\
\text { evels, respe }\end{array}$ & $\begin{array}{l}\text { a bank. Bu } \\
\text { ble equal to } \\
\text { essed as the } \\
\text { e, respective } \\
\text { members or } \\
\text { er. Board ed } \\
\text { orted in pa } \\
\text { ly. }\end{array}$ & $\begin{array}{l}\text { iness model } \\
1 \text { if a bank } \\
\text { logarithm of } \\
\text { y. GDP is th } \\
\text { the board. C } \\
\text { cation is the } \\
\text { entheses. Sta }\end{array}$ & $\begin{array}{l}\text { operative bar } \\
\text { the ratio of } \\
\text { listed in a sto } \\
\text { 2OE. Abnorn } \\
\text { Gross Dome } \\
\text { operative dur } \\
\text { roportion of } \\
\text { dard errors }\end{array}$ & $\begin{array}{l}\text { ks and bank } \\
\text { oans to total } \\
\text { k exchange } \\
\text { al NPL is a } \\
\text { tic product. } \\
\text { imy is equal } \\
\text { irector who } \\
\text { re robust to }\end{array}$ \\
\hline
\end{tabular}


As regards the second step, we find a positive relationship between the Z-index and the dummy cooperative (column 3). In the third step we test the impact of the mediators on the bank risk (column 4). Specifically, we note that the first mediator variable, namely board turnover, does not affect bank risk $(\beta=2.052, \mathrm{p}>10 \%)$, while the second mediator, the board education, has a highly significant and negative effect on bank risk $(\beta=-0.536, \mathrm{p}<$ $0.1 \%$ ). We conclude that there is no mediation of the board turnover. In the last step (column 5), we observe that when the board turnover is added to the model with the independent variable, the latter remains significant $(\beta=$ $0.367, \mathrm{p}<0.1 \%$ ) and the coefficient of the cooperative dummy increases from 0.257 (in column 3) to 0.367 (column 5). Overall, we find that board turnover does not mediate the relationship between the cooperative status of a bank and the bank risk, but it acts as suppressor variable. Finally, in column (6), we show that the coefficient of the cooperative dummy variable is reduced in its effect and significance $(\beta=0.191, \mathrm{p}>10 \%)$ when the board education is added to the model while the board education remains significant $(\beta=-0.411, \mathrm{p}<5 \%)$. Thus, our evidence confirm that board education mediates the relationship between the cooperative status of a bank and the bank risk as measured by Z-index.

Similar results are obtained when bank risk is measured as profit volatility $\sigma(\mathrm{ROA})$. From column (7) we show that our independent variable has a highly significant and negative impact on the bank risk, suggesting that cooperative banks are significantly less risky than joint stock banks. In column (8), we show that while the board turnover does not affect the $\sigma(\mathrm{ROA})(\beta=-1.701, \mathrm{p}>10 \%)$, the board education has a highly significant and positive effect on bank risk $(\beta=0.536, \mathrm{p}<1 \%)$. Therefore, we can conclude that board turnover does not mediate the relationship between cooperative status and bank risk taking. In fact, in column (9) we observe that when the board turnover is added to the model with the independent variable, the latter remains significant $(\beta=-0.422, \mathrm{p}<$ $0.1 \%$ ) and the coefficient of the cooperative dummy increases from -0.323 (in column 7) to -0.422 (column 9). Again, we can conclude that board turnover does not mediate the relationship between the cooperative status of a bank and the bank risk. Finally, in column (10) we show that when the board education is added to the model the coefficient of the cooperative-status dummy variable remains significant $(\beta=-0.264, \mathrm{p}<5 \%)$ as well as the mediator variable $(\beta=0.343, \mathrm{p}<5 \%)$. However, the coefficient of the cooperative-status dummy variable is reduced from -0.422 (in column 9) to -0.264 (column 10), and the significance level of the coefficient is reduced from $0.1 \%$ to $5 \%$. Thus, we can conclude that board education partially mediates the relationship between the cooperative status of a bank and the bank risk as measured by the profit volatility. Therefore, it seems that in cooperative banks the low board education could contribute to explain the low risk taking of cooperative compared to joint stock banks.

\section{Conclusions}

Based on a comprehensive sample of cooperative and joint stock banks, this study contributes to the literature and the current policy debate on bank governance for cooperative banks in several respects. Although bank governance is a subject of wide debate in the literature, to the authors' knowledge, no empirical study has so far focused on risk-taking of banks distinguishing between cooperative and joint stock banks. This distinction is important to adequately assess the board dynamics on risk-taking, given the quite different business models and objectives that these two types of banks put in place but also to understand whether such differences are large enough to justify the claim for different corporate governance standards between them, as suggested by the European Association of Cooperative banks.

Our first result has shown that cooperative banks are less risk taker than joint stock banks, as suggested by the theoretical literature. Secondly, we have shown that the two types of banks are quite different in their boards' characteristics, with cooperative banks having lower board turnover and education than joint stock banks, both commonly considered as an indication of weak governance. Our third result show that cooperative banks' lower risk-taking is partially driven by the lower level of education of directors seated in the board. A comprehensive interpretation of these results lead to the conclusion that a lower level of board education, can prevent the exposure to risks that the management is unable to understand, and is also probably compensated by the higher experience (low turnover) of the directors. Therefore, low board education could (involuntary) prevent the boards of cooperative banks from undertaking projects whose risks cannot be understood or even accessed (knowledge barrier). On the contrary, joint-stock banks, which are characterized by stronger incentives to maximize shareholder value and more educated boards, tend to undertake more of these sophisticated risks which materialized as losses during the crisis (Minton et al., 2014). 
Regarding the current debate on governance standards for cooperative banks, our evidence is far from suggesting that less-educated board is a desirable feature of banks' boards. In this respect, our evidence highlight that the weakness of the cooperative bank governance model (Borgen, 2004; Hart \& Moore, 1998) remains an issue even in light of their stronger resilience to the crisis.

\section{References}

Alexopoulos, Y., Catturani, I., \& Goglio, S. (2013). Searching for a model of governance in cooperative banking. In D. Brazda, J., Dellinger, M., Rößl (Ed.), Bestandsaufnahme und Ausgangssituation (pp. 707-731). Wien: Lit Verlag.

Andres, P. De, \& Vallelado, E. (2008). Corporate governance in banking: The role of the board of directors. Journal of Banking and Finance, 32(12), 2570-2580.

Baron, R. M., \& Kenny, D. A. (1986). The Moderator-Mediator Variable Distinction in Social Psychological Research: Conceptual, Strategic, and Statistical Considerations. Journal of Personality and Social Psychology, 51(6), 1173-1182.

Basel Committee on Banking Supervision. (2015). Guidelines on Corporate governance principles for banks. Retrieved from http://www.bis.org/bcbs/publ/d328.pdf

Battistin, E., Graziano, C., \& Parigi, B. M. (2012). Connections and performance in bankers' turnover. European Economic Review, 56(3), 470-487.

Becchetti, L., Garcia, M. M., \& Trovato, G. (2011). Credit Rationing and Credit View: Empirical Evidence from an Ethical Bank in Italy. Journal of Money, Credit and Banking, 43(6), 1217-1245.

Beck, T., Behr, P., \& Guettler, A. (2013). Gender and banking: Are women better loan officers? Review of Finance, 17(4), 1279-1321.

Beck, T., De Jonghe, O., \& Schepens, G. (2013). Bank competition and stability: Cross-country heterogeneity. Journal of Financial Intermediation, 22(2), 218-244.

Bellucci, A., Borisov, A., \& Zazzaro, A. (2010). Does gender matter in bank-firm relationships? Evidence from small business lending. Journal of Banking and Finance, 34(12), 2968-2984.

Berger, A. N., Kick, T., \& Schaeck, K. (2014). Executive board composition and bank risk taking. Journal of Corporate Finance, 28, 48-65.

Bertrand, M., \& Mullainathan, S. (2003). Enjoying the Quiet Life? Corporate Governance and Managerial Preferences. Journal of Political Economy, 111(5), 1043-1075.

Bertrand, M., \& Schoar, A. (2003). Managing with Style: The Effect of Managers on Firm Policies. The Quarterly Journal of Economics, 118(4), 1169-1208.

Blundell, R., \& Bond, S. (1998). Initial conditions and moment restrictions in dynamic panel data models. Journal of Econometrics, 87(1), 115-143.

Bofondi, M., \& Gobbi, G. (2006). Informational barriers to entry into credit markets. Review of Finance.

Borgen, S. O. (2004). Rethinking incentive problems in cooperative organizations. Journal of Socio-Economics, 33(4), 383-393.

Boytsun, A., Deloof, M., \& Matthyssens, P. (2011). Social Norms, Social Cohesion, and Corporate Governance. Corporate Governance: An International Review, 19(1), 41-60.

Carducci, B., \& Wong, A. (1998). Type A and risk taking in everyday money matters. Journal of Business and Psychology, 12(3), 355-359.

Chaddad, F. R., \& Cook, M. L. (2004). Understanding new cooperative models: An ownership-control rights typology. Review of Agricultural Economics, 26(3), 348-360.

Chaganti, R. S., Mahajan, V., \& Sharma, S. (1985). Corporate Board Size, Composition and Corporate Failures in Retailing Industry. Journal of Management Studies, 22(4), 400-417.

Cornforth, C. (2004). The Governance of cooperatives and mutual associations: A paradox perspective. Annals of Public and Cooperative Economics, 75(1), 11-32.

De Nicoló, G., Jalal, A. M., \& Boyd, J. H. (2006). Bank Risk-Taking and Competition Revisited: New Theory and New Evidence. IMF Working Papers, 06(297), 1.

Delis, M. D., Hasan, I., \& Tsionas, E. G. (2014). The risk of financial intermediaries. Journal of Banking \& Finance, 44(March), 1-12. 
Delis, M. D., \& Kouretas, G. P. (2011). Interest rates and bank risk-taking. Journal of Banking and Finance, $35(4), 840-855$.

Delis, M. D., \& Staikouras, P. (2009, August 17). On-site audits, sanctions, and bank risk-taking: An empirical overture towards a novel regulatory and supervisory philosophy. Retrieved from https://mpra.ub.unimuenchen.de/16836/1/MPRA_paper_16836.pdf

Delis, M. D., \& Staikouras, P. K. (2011). Supervisory effectiveness and bank risk. Review of Finance, 15, 511543.

Dyck, A., Morse, A., \& Zingales, L. (2010). Who blows the whistle on corporate fraud? Journal of Finance, $65(6), 2213-2253$.

Eldenburg, L., Hermalin, B. E., Weisbach, M. S., \& Wosinska, M. (2004). Governance, performance objectives and organizational form: Evidence from hospitals. Journal of Corporate Finance, 10(4), 527-548.

European Association of Co-operative Banks. (2015). EACB Note on BCBS Guidelines on Corporate Governance Principles for Banks, 1-9. Retrieved from http://www.globalcube.net/clients/eacb/content/medias/publications/position_papers/Corporate_Governan ce/150109_EACB_note_on_BCBS_review_of_Corporate_Governance_Principles_final.pdf

Fiordelisi, F., \& Mare, D. S. (2013). Probability of default and efficiency in cooperative banking. Journal of International Financial Markets, Institutions and Money, 26(1), 30-45.

Fonteyne, W. (2007). Cooperative Banks in Europe - Policy Issues (Working Paper No. 07/159). Retrieved from https://www.imf.org/external/pubs/ft/wp/2007/wp07159.pdf

García-Marco, T., \& Robles-Fernández, M. D. (2008). Risk-taking behaviour and ownership in the banking industry: The Spanish evidence. Journal of Economics and Business, 60(4), 332-354.

Giagnocavo, C., Gerez, S., \& Sforzi, J. (2012). Cooperative bank strategies for social-economic problem solving: Supporting social enterprise and local development. Annals of Public and Cooperative Economics, 83(3), $281-315$

Gorton, G., \& Schmid, F. (1999). Corporate governance, ownership dispersion and efficiency: Empirical evidence from Austrian cooperative banking. Journal of Corporate Finance, 5(2), 119-140.

Grable, J. (2000). Financial risk tolerance and additional factors that affect risk taking in everyday money matters. Journal of Business and Psychology, 14(4), 625-630.

Groeneveld, H., \& de Vries, B. (2009). European co-operative banks : First lessons of the subprime crisis. The International Journal of Cooperative Management, 4(2), 8-21.

Guiso, L., Sapienza, P., \& Zingales, L. (2009). Does local financial development matter? In The Banks and the Italian Economy (pp. 31-66).

Hansmann, H. (2000). The ownership of enterprise. Cambridge (MA): Harvard University Press.

Hardesty, S. D. (2005). Cooperatives as Marketers of Branded Products. Journal of Food Distribution Research, $36(1), 237-242$.

Hart, O., \& Moore, J. (1998). Cooperatives vs. outside ownership. NBER Working paper (Vol. 6421). https://doi.org/10.3386/w6421

Keeling, J. J. (2004). Lessons in Cooperative Failure: The Rice Growers Association Experience. Agricultural Research in Economics, 7(3), 1-5.

Köhler, M. (2014). Which banks are more risky? The impact of business models on bank stability. Journal of Financial Stability, 16, 195-212.

Laeven, L., \& Levine, R. (2009). Bank governance, regulation and risk taking. Journal of Financial Economics, 93(2), 259-275.

Minton, B. A., Taillard, J. P., \& Williamson, R. (2014). Financial Expertise of the Board, Risk Taking, and Performance: Evidence from Bank Holding Companies. Journal of Financial \& Quantitative Analysis, 49(2), 351-380.

Nakano, M., \& Nguyen, P. (2012). Board Size and Corporate Risk Taking: Further Evidence from Japan. Corporate Governance (Oxford), 20(4), 369-387.

Nicols, A. (1967). Property rights and behavior: Stock versus mutual Savings and Loan Associations: Some evidence of differences in behavior. American Economic Review, 57(3), 337-346.

Palvia, A., Vähämaa, E., \& Vähämaa, S. (2014). Are Female CEOs and Chairwomen More Conservative and Risk Averse? Evidence from the Banking Industry During the Financial Crisis. Journal of Business Ethics, $131(3), 577-594$. 
Pathan, S. (2009). Strong boards, CEO power and bank risk-taking. Journal of Banking and Finance, 33(7), $1340-1350$.

Schaeck, K., \& Cihák, M. (2014). Competition, Efficiency, and Stability in Banking. Financial Management, $43(1), 215-241$.

Shaw, L. (2006). Overview of Corporate Governance Issues for Co-operatives. Global Corporate Governance Forum, (November 2006), 1-40.

Spear, R. (2004). Governance in Democratic Member-Based Organisations. Annals of Public and Cooperative Economics, 75(1), 33-60.

Stefancic, M. (2014). Investigating Management Turnover in Italian Cooperative Banks. Journal of Entrepreneurial and Organizational Diversity, 3(1), 131-163.

Vitaliano, P. (1983). Cooperative Enterprise: An Alternative Conceptual Basis for Analyzing a Complex Institution. American Journal of Agricultural Economics, 65(5), 1078. 